JAZYKOVEDNÝ ČASOPIS, 2016, roč. 67, č. 1

\title{
ON THE RHYTHMIC LAW AND THE SUFFIX -ár*
}

\author{
MARTIN PUKANEC \\ UFR Lettres, Langues et Sciences Humaines, Université Blaise Pascal, France \\ Filozofická fakulta, Univerzita Konštantína Filozofa v Nitre
}

PUKANEC, Martin: On the Rhythmic Law and the Suffix -ár. Journal of Linguistics, 2016, Vol. 67, No 1, pp. $45-51$.

\begin{abstract}
The purpose of this paper is to examine the violations of the Rhythmic Law in the words with the suffix -ár related to the L'ubomír Kralčák’s inspiring paper On the Vocal Quantity Stability in the Slovak Suffix -ár (-áreň). I propose here a regressive rhythmic law according to which the Proto-Slovak roots of the AP (b) regularly shortened when followed by the suffix -ár. The proposed sound law operated in Proto-Slovak, before the definitive fixation of the stress on the initial syllable in Slovak and before the Slovak Rhythmic Law.

Keywords: etymology, Rhythmic Law, Slavic accentology, Slavic languages, Slovak language
\end{abstract}

The Rhythmic Law is a relatively unique rule which applies to both the Slovak standard language and the central Slovak dialects. The law was first discovered by Ludevít Štúr in Nauka reči slovenskej: "V čistej Slovenčiňe ňikd’e dve dlhje silabi jedna za druhou ňeprichod’ja a čo bi aj jedna podla povahi svojej mala bit' dlhá, skráca sa, ked' predchádzajúca je dlhá. Dvojhláska sa t’jež za dlhú považuje" (Štúr, 1846, p. 104). The Rhythmic Law specifies that two long vowels may not occur in two consecutive syllables of a single word; whenever two phonemically long elements are joined to each other, the second one automatically shortens (Krajčovič, 1975 , pp. $62-63$ ), but it is not an absolute and exceptionless law. As regards its origin, it is treated as a specific central Slovak response to vowel contraction (Feldstein, 1990, pp. $41-42$, 48; cf. Pauliny, 1963, p. 143), which started in the $10^{\text {th }}$ century. The purpose of this paper is to examine the violations of the Rhythmic Law in the words with the suffix -ár related to the L'ubomír Kralčák's inspiring paper O kvantitativnej stabilite sufixu -ár (-áreñ) - On the Vocal Quantity Stability in the Slovak Suffix -ár (-árěn).

In this paper Kralčák (2007, pp. 362 - 363) states that "Pokial' ide o distribúciu kvantity z diachrónneho hl'adiska, možno všeobecne konštatovat', že pre výskyt kvantity v stavbe súčasného slovenského slova bola rozhodujúca zmena kvantita-

* Note of the editor: At the author's request the editors have not interfered in the text of paper. The author is responsible for the linguistic and formal level of the text and of the bibliographic references.

Red. poznámka: Na žiadost' autora redakcia nezasahovala do textu príspevku. Za jazykovú a formálnu úroveň textu príspevku a bibliografických odkazov zodpovedá autor. 
tívnych pomerov po reštrukturalizácii prozodických vlastností praslovanského základu formujúcej sa slovenčiny v 10. storočí. Pritom pre slovenčinu je typické, že novoakútová intonácia sa $\mathrm{v}$ podstate dôsledne prehodnotila ako dížka a všetky ostatné intonácie (akútová, cirkumflexová i nová cirkumflexová) sa, naopak, vo väčšine prípadov prehodnocovali ako krátkost' (porov. Pauliny, 1963, s. 138 n.). Novoakútová kvantita (kvantita za novú razenú intonáciu) tak v slovenčine vystupuje už celé tisícročie ako jej vel'mi zretel’ná, dominantná a zároveň stabilná prozodická vlastnost'." Moreover, Kralčák shows "slová, v ktorých sa dížka slovotvorného základu ustanovila historicky za praslovanský novoakút," and "[k] takémuto zdíženému základu sa pri d’alšom odvodzovaní pridáva dlhý sufix -ár s rovnakým stabilným novoakútovým dedičstvom kvantity."

The starting-point of modern Slavic accentology is the publication of Stang's Slavonic accentuation (1957). Stang established three (Late) Proto-Slavic accent paradigms - AP (a), AP (b) and AP (c), each with its own prosodic characteristics:

(a) Fixed stress on the stem. If the stem is monosyllabic, the stressed syllable is "acute", i.e. we find a short rising tone on a historically "long" syllable. A special class is formed by nouns of the so-called *volla type, where the root has neo-acute intonation. There are good arguments to classify them as belonging to AP (b).

(b) The stress alternates between the last syllable of the stem and the first syllable of the ending. Stem-stressed forms have a rising tone with retention of the old quantity of the syllable. This tone is called "neo-acute". Forms with stress on the ending have a short rising tone.

(c) The stress alternates between the first syllable of the stem and the ending. Stem-stressed forms have a falling tone and lose the stress to a clitic. Endstressed forms usually have a short rising accent, but in some cases a long rising accent. The falling tone is sometimes referred to as "circumflex" (Derksen, 2008, p. 8).

After these general points, let us have a look at the Proto-Slavic nomina agentis ending in *-ārb in the Russian etymological dictionary Этимологический словарь славянских языков (ESSJ) that is incomplete (the latest volume being *otъtęti *ozgoba) but relatively thorough:

*bъdn-ārb, a derivative of *bъdbna/*bъdbnъ > Slovak bednár (ESSJ 3, 1976, p. 114); *drъv-ārb, a derivative of *drъvo > Slovak drevár (ESSJ 5, 1978, p. 140); *gosl'-ärb, a derivative of *gosl'/*gosli > Slovak husliar (ESSJ 7, 1980, pp. 84 - 85);

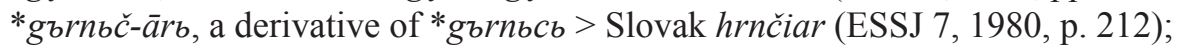
*kop-ārb, a derivative of *kopati > Slovak kopár (ESSJ 11, 1984, p. 18); *korv-ārb, a derivative of *korva > Slovak kraviar (ESSJ 11, 1984, p. 116); *kos-ārb, a derivative of *kosa > Slovak kosiar (ESSJ 11, 1984, pp. 135 - 136); *kotbl'-ärb, a derivative of *kotblı > Slovak kotlár (ESSJ 11, 1984, pp. 215 - 216); *kov-ārb, a derivative of *kovati (ESSJ 12, 1985, pp. 8 - 9) > Slovak kovár; 
*koz-ārb, a derivative of *koza (ESSJ 12, 1985, pp. 21 - 22) > Slovak koziar;

*lěk-ārb, a derivative of *lěka/*lěkb > Slovak lekár (ESSJ 14, 1987, pp. 194 - 195);

*lěs-ārb, a derivative of *lěsz (ESSJ 14, 1987, p. 236);

*lixv-ārb, a derivative of *lixva (ESSJ 15, 1988, p. 99) > Slovak lichvár;

*loj-ārb, a derivative of *lojiti (ESSJ 15, 1988, pp. 255 - 256);

*lıg-ārb, a derivative of *lıgati > Slovak luhár (ESSJ 16, 1990, pp. 232 - 233);

*lıžbk-ārb, a derivative of *lıžbka > Slovak loškár (ESSJ 17, 1990, p. 9);

*lbn-ārb, a derivative of *lbnъ > Slovak l'anár (ESSJ 17, 1990, p. 82);

*masl-ārb, a derivative of *maslo (ESSJ 17, 1990, p. 222) > Slovak masliar;

*med-ārb, a derivative of *med (ESSJ 18, 1993, p. 43) > Slovak medár;

*melk-ārb, a derivative of *melko > Slovak mliekár (ESSJ 18, 1993, p. 84);

*met-ārb, a derivative of *metati (ESSJ 18, 1993, p. 112);

*metzl-ārb, a derivative of *metzla > Slovak metlár (ESSJ 18, 1993, p. 127);

*méd-ārb, a derivative of *mědb > Slovak mediar (ESSJ 18, 1993, p. 139);

*męs (")-ärb, a derivative of *męso > Slovak mäsiar (ESSJ 19, 1992, p. 6);

*mlin-ārb, a derivative of *mlinъ > Slovak mlynár (ESSJ 19, 1992, pp. 65 - 66);

*most-ārb, a derivative of *mostz > Slovak mostár (ESSJ 20, 1994, pp. 21 - 22);

*moč-ārb, a derivative of *moka 'flour' > Slovak múčiar (ESSJ 20, 1994, p. 112);

Slovak mučiareň, a derivative of *moka 'torture', is a more recent formation;

*mok-ārb, another derivative of *moka 'flour' (ESSJ 20, 1994, p. 138);

*mux-ārb, a derivative of *muxa > (ESSJ 20, 1994, pp. 173 - 174);

*mblin-ārb, a derivative of *mъlinъ > Slovak mlynár again (ESSJ 20, 1994, p. 223);

*mydl(')-ārb, a derivative of *mydlo > Slovak mydlár (ESSJ 21, 1994, pp. 26 - 27);

*myt-ārb, a derivative of *myto (ESSJ 21, 1994, pp. 73 - 74);

All the relevant words in the list verify the vocal quantity stability in the Slovak suffix -ár from the $10^{\text {th }}$ century onwards, which is a rather unique phenomenon in the Slavic area. The Proto-Slavic suffix *-ārb is attested in Old Church Slavic already and the oldest words with the suffix -ár attested in Slovak (cf., e.g., Krajčovič, 2005, pp. 108 - 110) are tesár (tazzar, 1075), hrnčiar (grincha, 1113) and štitár (scitar, 1113). The form tazzar 'carpenter' is apparently a proof of the vocal quantity in the suffix. However, I am much more skeptical about the vocal quantity stability in the root of the words with the suffix -ár. Two examples in the list preserve the quantity, regardless of the Rhythmic Law, of course, *melk-ārb, a derivative of *melko, Slovak mliekár, and *mǒ̌-ārb, a derivative of *moka, Slovak múčiar, but the word *lěk-ārb in the list, lekár in Slovak, makes it problematic.

Proto-Slavic *melko is reconstructed on the basis of Old Church Slavic mlěko, Bulgarian mljáko, Macedonian mleko, Serbian-Croatian mlijèko, mlīkö, Slovenian mléko, Sorbian mloko, Czech mléko, Slovak mlieko, Polish mleko, Russian and Ukrainian molokó, Belorussian malakó (ESSJ 18, 1993, pp. 84 - 85), the reconstruction of Proto-Slavic *moka is based on Church Slavic moka, SerbianCroatian múka, mūkä, Slovenian móka, Old Czech múka, Czech mouka, Slovak 
múka, Polish mąka, Russian, Ukrainian and Belorussian muká (ESSJ 20, 1994, pp.

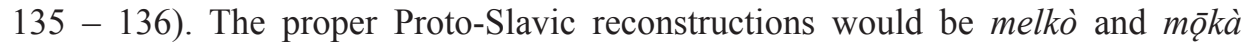
respectively. Both words belong to the AP (b). The word *lékb is reconstructed on the basis of Bulgarian lek, Macedonian lek, Serbian-Croatian lijek, Slovenian lék, Upper Sorbian lěk, Czech lék, Slovak liek, Polish lek, Old Russian lěk lik (ESSJ 14, 1987, pp. 192 - 193) and must also belong to the AP (b). However, the vocal quantity in the root of the derivative lekár has not been preserved. By the way, in these cases a rhythmic law operated perfectly in Czech: mlékař, moukař $(<* m o$ kārb) and lékắ.

The Slovak word lekár is not the so-called exception confirming the rule, I am afraid. There are too many candidates for that. The above-mentioned word štitár, attested as a toponym in 1113, is a very serious one. Slovak štitár is a derivative of Proto-Slavic *ščitb (Serbian-Croatian štît, G sg. štita, Slovenian ščit, G sg. ščita, Russian ščit, G sg. ščitá, Czech and Slovak štit), which belongs to the AP (b). The word bedár seems to be another good example belonging to the AP (b), although the meaning must have been radically changed. And the Proto-Slavic words *pbsàti, Slovak písat', as well as *gvězdà, Slovak hviezda, *kònı, Slovak kôn̆, *nöžb, Slovak nôzz, or *stòlı, Slovak stôl, all belonging to the AP (b) (cf. Derksen, 2008, pp. 487, $38-39,430,195,231,358,468)$, yielded Slovak pisár, hvezdár, koniar, nožiar and stolár respectively. The Czech forms štitar̆ and pisar̆, where a rhythmic law operated, show that at least these two words should be of Proto-Slavic origin.

Slovak vinár, a derivative of vino, which is a very old borrowing belonging to the AP (b), should be of Proto-Slavic origin as well. Furthermore, the abovementioned standardized mliekár is attested in dialects as mlekár (standardized as such in 1931, cf. Pravidlá slovenského pravopisu, 1931, p. 180), and the remaining word which violates the Rhythmic Law, múciar, must preserve the vowel quantity in the root just because mučiar would mean 'torturer'. Note that the Slovak words lekár, štitár, bedár, pisár, hvezdár, koniar, nožiar, stolár and vinár are not a proof of Štúr's progressive Rhythmic Law (whenever two phonemically long elements are joined to each other, the second one automatically shortens), they are a proof of the stronger vocal quantity stability in the suffix -ár in comparison with the one in the root in Slovak. The length in the Slovak suffix -ár has always been a survivor, the one in the root not. The Middle High German borrowings $m \bar{u} r-m \bar{u}$ raere $>$ Slovak múr - murár (cf. Machek, 1968, p. 383) prove it very clearly.

I would propose here a regressive rhythmic law according to which the ProtoSlovak roots of the AP (b) regularly shortened when followed by the suffix -ár (the shortened roots of the AP (b) were then analogical to the other roots ending in -ár and respected the rhythmicity). The proposed sound law operated only in ProtoSlovak, before the definitive fixation of the stress on the initial syllable in Slovak (and apparently before the Slovak Rhythmic Law), but an analogical principle is not unknown even today: archiv - archivár, etc. Slovak cisár 'emperor', which is 
a relatively new loanword from Czech, is a very interesting analogy, because this word does not belong to nomina agentis ending in -ár (Gaius Julius Caesar > Gothic kaisar > Proto-Slavic *cěsarjb > Old Czech ciesař > Czech císař would have normally yielded Slovak císar), and proves the extreme vocal quantity stability in the Slovak suffix -ár as well as the instability of length before this suffix around the $16^{\text {th }}$ century.

Moreover, as can be seen in the contemporary examples provided by L. Kralčák (2007, p. 363): bábka - bábkár, bájka - bájkár, hádka - hádkár, prekážka prekážkár, rozprávka - rozprávkár, sánka - sánkár, stávka - stávkár, trúbka trúbkár, vážka - vážkár, výška - výškár, známka - známkár, cievka-cievkár, čiapka - čiapkár, čučoriedka - čučoriedkár, dial'ka - dial'kár, hliadka - hliadkár, klietka klietkár, lahôdka - lahôdkár, obrázok - obrázkár, omietka - omietkár, pamiatka pamiatkár, pochôdzka - pochôdzkár, polievka - polievkár, retiazka - retiazkár, sviečka - sviečkár, škôlka - škôlkár, článok - článkár, krúžok - krúžkár, obrázok obrázkár, párok - párkár, prútok - prútkár, stánok - stánkár, súdok - súdkár, žalúdok-žalúdkár, korienok-korienkár, oštiepok-oštiepkár, pasienok-pasienkár, záhumienok - záhumienkár, etc., the cluster CONSONANT $+\mathrm{K}$ before the suffix -ár is easily able to block the operation of the Rhythmic Law, which is another proof, although rather recent, of the vocal quantity stability in the suffix -ár in Slovak.

Nowadays, the millennial vocal quantity stability in the Slovak suffix -ár as well as the obvious CONSONANT $+\mathrm{K}$ cluster blockage of the Rhythmic Law before the suffix -ár having been ignored by several codifiers of the Slovak standard language, but this is of no importance for the present discussion. Nevertheless, a short note might be in order. These liberal Slovak codifiers who refuse to conserve the unique thousand-year-old heritage in Slovak dialects and follow the abovementioned tendencies in western dialects of Czech-Slovak are regarded as being "purist", which is not very clear to a historical linguist.

\section{References}

DERKSEN, Rick: Etymological Dictionary of the Slavic Inherited Lexicon. Leiden - Boston: Brill 2008.

ESSJ 3 - Этимологический словарь славянских языков. Праславянский лексический фонд. Выпуск 3. *bratrьсь - *cьrky. Hl. red. О. Н. Трубачев. Москва: Наука 1976.

ESSJ 5 - Этимологический словарь славянских языков. Праславянский лексический фонд. Выпуск 5. *dělo - *dьržьlь. H1. red. О. Н. Трубачев. Москва: Наука 1978.

ESSJ 7 - Этимологический словарь славянских языков. Праславянский лексический фонд. Выпуск 7. *golvačь - *gyžati. Hl. red. О. Н. Трубачев. Москва: Наука 1980.

ESSJ 11 - Этимологический словарь славянских языков. Праславянский лексический фонд. Выпуск 11. *konьсь - *kotьna(ja). Hl. red. О. Н. Трубачев. Москва: Наука 1984.

ESSJ 12 - Этимологический словарь славянских языков. Праславянский лексический фонд. Выпуск 12. *koulъkъ - *kroma/kromъ. Hl. red. О. Н. Трубачев. Москва: Наука 1985. 
ESSJ 14 - Этимологический словарь славянских языков. Праславянский лексический фонд. Выпуск 14. *labati - *lěteplъjь. Нl. red. О. Н. Трубачев. Москва: Наука 1987.

ESSJ 15 - Этимологический словарь славянских языков. Праславянский лексический фонд. Выпуск 15. *lětina - *lokačь. Hl. red. O. Н. Трубачев. Москва: Наука 1988.

ESSJ 16 - Этимологический словарь славянских языков. Праславянский лексический фонд. Выпуск 16. *lokadlo - *lъživьсь. H1. red. О. Н. Трубачев. Москва: Наука 1990.

ESSJ 17 - Этимологический словарь славянских языков. Праславянский лексический фонд. Выпуск 17. *1ъžь - *matješьnъjь. Hl. red. О. Н. Трубачев. Москва: Наука 1990.

ESSJ 18 - Этимологический словарь славянских языков. Праславянский лексический фонд. Выпуск 18. *matoga - *mękyšьka. Hl. red. О. Н. Трубачев. Москва: Наука 1993.

ESSJ 19 - Этимологический словарь славянских языков. Праславянский лексический фонд. Выпуск 19. *mе̨s( ${ }^{()}$arь - *morzakъ. Hl. red. О. Н. Трубачев. Москва: Наука 1992.

ESSJ 20 - Этимологический словарь славянских языков. Праславянский лексический фонд. Выпуск 20. *morzatъjь - *mъrsknǫti. Hl. red. О. Н. Трубачев. Москва: Наука 1994.

ESSJ 21 - Этимологический словарь славянских языков. Праславянский лексический фонд. Выпуск 21. *mъrskovatъjь - *nadějьnъjь. Hl. red. О. Н. Трубачев. Москва: Наука 1994.

FELDSTEIN, Ronald F.: Praslovanské prozodické pozadie vzniku rytmického zákona v slovenčine. In: Slavica Slovaca, 1990, roč. 25, č. 1, pp. $41-49$.

KRAJČOVIČ, Rudolf: A historical phonology of the Slovak language. Heidelberg: Winter 1975.

KRAJČOVIČ, Rudolf. Živé kroniky slovenských dejín skryté v názvoch obcí a miest. Bratislava: Literárne informačné centrum 2005.

KRALČÁK, Lubomír: O kvantitatívnej stabilite sufixu -ár (-áreň). In: Slovenská reč, 2007, roč. 72 , č. 6 , pp. $355-370$.

MACHEK, Václav: Etymologický slovník jazyka českého. Praha: Academia 1968.

PAULINY, Eugen: Fonologický vývin slovenčiny. Bratislava: Vydavatel'stvo Slovenskej akadémie vied 1963.

Pravidlá slovenského pravopisu. Praha: Matica slovenská 1931.

ŠTÚR, Ludevít: Nauka reči slovenskej. Prešporok: Tatrín 1846.

\section{Resumé}

\section{K RYTMICKÉMU ZÁKONU A PRÍPONE -ár}

Rytmický zákon či pravidlo o rytmickom krátení, ako ho objavil L'. Štúr, hovorí, že v tzv. čistej slovenčine ,„̌ikd’e dve dlhje silabi jedna za druhou ňeprichod’ja a čo bi aj jedna podla povahi svojej mala bit' dlhá, skráca sa, ked' predchádzajúca je dlhá“, ale toto pravidlo nie je platné absolútne. Cielom tohto príspevku je preskúmat' výnimky zo Štúrovho progresívneho pravidla o rytmickom krátení v činitel'ských menách na -ár a navrhujeme $\mathrm{v}$ ňom regresívne pravidlo o rytmickom krátení, ktoré v činitel'ských menách na -ár pôsobilo ešte pred Štúrovým pravidlom.

Na základe zoznamu slov praslovanských činitel'ských mien končiacich na *-ār z neúplného ruského etymologického slovníka Этимологический словарь славянских языков spochybňujeme kvantitatívnu stabilitu koreňov v slovenčine pred kvantitatívne vel’mi stabilnou príponou -ár. Dva príklady zo slovníka zachovávajú kvantitu v koreni, a to mliekár a múčiar, ale slovo lekár ju problematizuje. Slovenské mliekár je k praslovanskému *melkò, múčiar k praslovanskému *mōkà a lekár k praslovanskému * lěkz, pričom všetky tri praslovanské slová patria k dlhej Stangovej AP (b).

Výraz lekár nebude onou výnimkou potvrdzujúcou pravidlo, pretože slovo štitár, doložené v slovenčine už v roku 1113, je k praslovanskému *ščitb z AP (b), no a k tej istej paradigme môžeme zaradit' 
aj starobylé pomenovania bedár, pisár, hvezdár, koniar, nožiar, stolár a d’alšie, všetky s kvantitatívne vel'mi stabilnou príponou -ár, no s koreňom, ktorý sa skrátil. Toto sa týka aj výpožičiek. Praslovanského pôvodu určite bude napríklad výpožička víno, ktorá patrí k AP (b), pričom aj v činitel'skom mene vinár vidíme fungovat' akési regresívne pravidlo o rytmickom krátení. Navyše potenciálne výnimky z tohto pravidla, spomínané mliekár a múčiar, možno pomerne l’ahko vysvetlit', pretože múčiar sa nemohlo skrátit' na mučiar zo zjavných sémantických dôvodov a mliekár je v príslušných nárečiach doložené ako mlekár (takto je ostatne aj kodifikované v Pravidlách slovenského pravopisu z roku 1931).

Výraznými argumentmi v prospech existencie regresívneho pravidla o rytmickom krátení v slovenských činitel'ských menách na -ár, ktoré navrhujeme, sú niektoré mladšie výpožičky. V slovenčine máme napríklad dve výpožičky zo strednej hornej nemčiny mūr - mūraere > múr - murár, teda so zjavným skrátením pred príponou -ár. Ešte zaujímavejšou je relatívne nová výpožiččka z češtiny cisár, ktorá ani nie je činitel'ským menom na -ár: Gaius Iulius Caesar > gótske kaisar > praslovanské *cěsarjb > staročeské ciesař > české císař by za normálnych okolností malo dat' slovenské císar, ktoré by bolo v súlade so Štúrovým progresívnym pravidlom o rytmickom krátení, ale zmenilo sa na spomínané cisár, čo dokazuje mimoriadnu životaschopnost' kvantity sufixu -ár, ako aj neživotaschopnost' kvantity pred touto príponou ešte okolo 16 . storočia.

Domnievame sa, že skutočnosti uvedené v našom príspevku teda dovol’ujú ustanovit’ hláskový zákon, podl’a ktorého vo formujúcej sa slovenčine kontinuanty z praslovančiny zachovali dížku v prípone -ár a korene z AP (b) obsahujúce pôvodnú dlhú samohlásku sa pred touto príponou pravidelne skracovali, a to ešte pred Štúrovým pravidlom. 